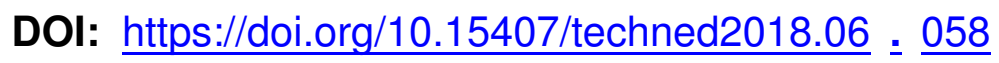

\title{
THE STATE OF WIND ENERGY IN POLAND
}

Journal

Publisher

ISSN

Issue

Pages
Tekhnichna elektrodynamika

Institute of Electrodynamics National Academy of Science of Ukraine 1607-7970 (print), 2218-1903 (online)

No 6, 2018 (November/December)

$58-61$

\section{Author}

\section{W. Dolega}

Faculty of Electrical Engineering; The Wroclaw University of Science and Technology, Wybrzeze Wyspianskiego 27, 50-370 Wroclaw, Poland

e-mail: waldemar.dolega@pwr.wroc.pl

\section{Abstract}

The process of current and future wind power development in Poland is analysed. Wind power worldwide and wind power in Poland are shown. Technical, economical and market potential of wind energy in Poland is defined. Analysis and assessment of wind power market in Poland in technical, economical and environmental aspects is made. Perspectives of wind power development up to 2020 are described. References 10, tables 2. 
Key words: wind power, development, state.

Received: 02.03 .2018

Accepted: 13.03 .2018

Published: 23.10 .2018

\section{References}

1. Act of 10 April 1997. The Energy Law. Journal of Laws of 2006. No 89. Item 625, with later changes.

2. Act of 20 February 2015. Renewable Energy Sources. Journal of Laws of 2015. Item 475, with later changes.

3. Act of 20 May 2016. On investments in wind farms. Journal of Laws of 2016. Item 961.

4. Activity of the President of Energy Regulatory Office in 2016. Report. The Energy Regulatory Office, Warsaw, 2017.

https://www.ure.gov.pl/pl/urzad/informacje-ogolne/sprawozdania/2916,Sprawozdania.htm I. (accessed January 15, 2018).

5. The state of wind energy in Poland in 2016. The Polish Wind Energy Association. Report. June 2017.

http://psew.pl/wp-content/uploads/2017/06/Stan-energetyki-wiatrowej-w-Polsce-w-2016-r.pdf . (accessed January 15, 2018).

6. Dolega W. Problems, barriers and perspectives of RES development in Poland. Trivent Publishing papers, 2016. Engineering and Industry Series

, Volume Power Systems, Energy Markets and Renewable Energy Sources in South-Eastern Europe. 2016. Volume 3. Pp. 265-282.

http://trivent-publishing.eu/engineeringandindustry.html (accessed January 15, 2018).

7. Dolega W. Perspectives of RES development in Poland up to 2020. Tekhnichna Elektrodynamika 2014. No 4. Pp. 29-31.

8. Dolega W. Wind power development in Poland. Tekhnichna Elektrodynamika. 2012. No 3. Pp. 99-100. 
9. Dolega W. Selected problems of expansion of renewable distributed generation - case study Poland. Institute of Electrodynamics of NAS of Ukraine, Kyiv, 2011. Research work compilation. Special issue. Part I. Pp. 36-43.

10. National potential of RES - Energy Regulatory Office. https://www.ure.gov.pl/pl/rynki-energii/energia-elektryczna/odnawialne-zrodla-ener/potencjal-kr ajowy-oze (accessed January 15, 2018).

PDF 